\title{
PENGGUNAAN MEDIA AUDIO VISUAL DALAM MENINGKATKAN MINAT BELAJAR PADA MATA PELAJARAN AL QURAN HADIS SISWA KELAS XI IPA MADRASAH ALIYAH (MA) AL MAUNAH DESA KEPUH KECAMATAN PALIMANAN KABUPATEN CIREBON
}

\author{
Khairunnisa, Nurwahdan, Wawan Ahmad Ridwan \\ Fakultas Ilmu Tarbiyah dan Keguruan \\ Institut Agama Islam Negeri Syekh Nurjati Cirebon \\ Email: Khaerun575@gmail.com
}

\begin{abstract}
ABSTRAK
Penelitian dalam skripsi ini dilatarbelakangi oleh pembelajaran Al Quran Hadis di Kelas XI IPA Madrasah Aliyah (MA) Al Maunah yang telah menggunakan media pembelajaran, seperti power point, akan tetapi perhatian dan minat siswa dalam pembelajaran masih relatif kurang. Untuk itu penggunaan media sangat dibutuhkan dalam rangka menciptakan suasana pembelajaran yang menyenangkan. Menggunakan media audio visual yang memadukan dua unsur sekaligus, yakni audio dan visual yang dapat dibuat semenarik mungkin diharapkan membuat pembelajaran menjadi lebih menyenangkan. Tujuan penelitian ini adalah untuk: (1) mengetahui penggunaan media audio visual dalam pembelajaran Al Quran Hadis, (2) mengetahui minat belajar siswa dengan menggunakan media audio visual dalam pembelajaran Al Quran Hadis, (3) mengetahui pengaruh penggunaan media audio visual terhadap minat belajar pada mata pelajaran Al Quran Hadis siswa kelas XI IPA Madrasah Aliyah (MA) Al Maunah Desa Kepuh Kecamatan Palimanan Kabupaten Cirebon. Penelitian berawal pemikiran bahwa penggunaan media audio visual yang dibuat semenarik mungkin dapat meningkatkan minat belajar siswa pada mata pelajaran Al Quran Hadis sehingga pembelajaran menjadi lebih efektif dan tujuan pembelajaranpun dapat tercapai. Jenis data yang digunakan peneliti ialah data kuantitatif. Metode pengumpulan data pada penelitian ini menggunakan observasi, angket dan dokumentasi. Hasil analisis pada penelitian yaitu penggunaan media
\end{abstract}


audio visual pada mata pelajaran Al-Qur`an Hadis berada pada kategori baik dengan prosentase mencapai $92 \%$, berada pada interval $75 \%$ - 100 $\%$, minat belajar dengan menggunakan media audio visual pada mata pelajaran Al Quran Hadis siswa kelas XI IPA Madrasah Aliyah (MA) Al Maunah sebesar 87,4 \% termasuk kategori baik, sedangkan pengaruh penggunaan media audio visual terhadap minat belajar pada mata pelajaran Al Quran Hadis siswa kelas XI IPA Madrasah Aliyah (MA) Al Maunah Desa Kepuh Kecamatan Palimanan Kabupaten Cirebon menggunakan perhitungan product moment diperoleh korelasi cukup atau sedang dengan nilai 0,60 yang berada pada rentang 0,40-0,70.

Kata kunci : Media Audio Visual, Minat Belajar dan Al Quran Hadis 


\section{A. Pendahuluan}

Pendidikan adalah usaha yang dilakukan oleh manusia dengan tujuan untuk mengembangkan potensi dirinya, hal ini sesuai dengan pasal 3 dari bab 2 Undang-Undang Republik Indonesia tentang Sistem Pendidikan Nasional yang menyatakan bahwa, "Pendidikan nasional berfungsi mengembangkan kemampuan dan membentuk watak serta peradaban bangsa yang bermartabat dalam rangka mencerdaskan kehidupan bangsa, bertujuan untuk berkembangnya potensi peserta didik agar menjadi manusia yang beriman dan bertakwa kepada Tuhan Yang Maha Esa, berakhlak mulia, sehat, berilmu, cakap, kreatif, mandiri, dan menjadi warga negara yang demokratis serta bertanggung jawab".

Dalam menumbuhkembangkan potensi diri tentunya melalui pendidikan, dan pendidikan didapatkan melalui proses pembelajaran. Proses pembelajaran yang dilaksanakan oleh guru dan siswa, yang mana guru dalam mengajar, hakikatnya bukan sekedar ceramah dan berdiri di depan kelas, akan tetapi bagaimana teknik dan strategi yang digunakan dapat berfungsi sebagai alat untuk mengirim ilmu pengetahuan, menyampaikan pesan/materi ajar, nilai-nilai, berinteraksi, mengorganisir, dan mengelola siswa sehingga dapat berhasil dan mencapai tujuan yang telah ditetapkan juga sekaligus merupakan pendidikan afektif dari satu generasi ke generasi berikutnya.

Menurut Asnawir dan Usman menjelaskan bahwa "Media merupakan sesuatu yang bersifat menyalurkan pesan dan dapat merangsang pikiran, perasaan, dan kemauan audien (siswa) sehingga dapat mendorong terjadinya proses belajar pada dirinya". ${ }^{2}$ Jadi, peranan media di sini adalah sebagai penyalur informasi pembelajaran yang ingin disampaikan guru kepada siswanya.. Selain itu media pembelajaran dapat mendorong motivasi dan minat belajar yang baru dalam diri siswa. Seperti

${ }^{1}$ UU RI No. 20 Tahun 2003. Sistem Pendidikan Nasional (Jakarta: Sinar Grafika, 2011),

7.

${ }^{2}$ Asnawir dan Usman, Basyiruddin, Media Pembelajaran (Jakarta: Ciputat Pers, 2002), 11. 
dikemukakan oleh Sudjana dan Rivai dalam Arsyad ,"... pembelajaran akan lebih menarik perhatian siswa sehingga dapat menumbuhkan motivasi belajar. ${ }^{3}$ Dan dalam Suprijanto terkait beberapa manfaat pembelajaran menggunakan media pembelajaran yaitu, “...mendorong minat belajar peserta didik, menambah variasi metode mengajar, menghemat waktu, ${ }^{4}$ Adapun definisi dari minat itu sendiri, menurut Slameto dalam Djaali menyatakan bahwa "Minat adalah rasa lebih suka dan rasa ketertarikan pada suatu hal atau aktivitas, tanpa ada yang menyuruh." 5

Namun perlu diingat bahwa peranan media tidak akan terlihat apabila penggunaannya tidak sejalan dengan esensi tujuan pembelajaran yang telah dirumuskan. Karena itu, tujuan pembelajaran harus dijadikan sebagai pangkal acuan untuk menggunakan media. Alasan lain penggunaan media dalam proses belajar-mengajar adalah berkenaan dengan taraf berpikir siswa. Taraf berpikir manusia mengikuti taraf perkembangan, dimulai dari berpikir abstrak menjadi berpikir konkret, dimulai dari berpikir sederhana ke kompleks. ${ }^{6}$ Penggunaan media pendidikan erat kaitannya dengan tahapan berpikir tersebut. Karena dengan media, hal-hal yang abstrak dapat dikonkretkan dan hal-hal yang kompleks dapat disederhanakan.

Berkenaan dengan pelajaran Al Quran Hadis di Madrasah Aliyah (MA), para siswa dituntut untuk mempelajari, memperdalam serta memperkaya kajian Al Qur'an dan Al Hadis serta memahami dan menerapkan tema-tema tentang manusia dan tanggung jawabnya di muka bumi, demokrasi serta pengembangan ilmu pengetahuan dan teknologi dalam perspektif Al Qur'an dan Al Hadis sebagai persiapan untuk hidup bermasyarakat agar menjadi pegangan dan pedoman hidup dalam

\footnotetext{
${ }^{3}$ Nana Sudjana dan Ahmad Rivai, Media Pengajaran (Bandung: Sinar Baru Algensindo,
} 2005), 28.

${ }^{4}$ Suprijanto, Pendidikan Orang Dewasa (Jakarta: PT. Bumi Aksara, 2005), 171.

${ }^{5}$ Haji Djaali, Psikologi Pendidikan (Jakarta: Bumi Aksara, 2014), 121.

${ }^{6}$ Nana Sudjana dan Ahmad Rivai, Media Pengajaran, 3. 
kehidupan sehari-hari. Hal ini berdasarkan pada ruang lingkup pembelajaran Al Quran Hadis yang terdapat dalam Lampiran Peraturan Menteri Agama RI Nomor 2 tahun 2008. Maka, meningkatkan minat dan motivasi peserta didik untuk mempelajari dan mempraktikkan ajaran dan nilai-nilai yang terkandung dalam al-Qur'an-hadis adalah suatu keharusan bagi seorang guru.

Jika mencermati dunia pendidikan, semakin bertambahnya waktu muncul silih berganti aneka inovasi dalam pembelajaran. Usaha yang ditempuh oleh para praktisi dunia pendidikan ini tak lain agar terciptanya suasana pembelajaran yang menyenangkan. Dengan semakin maju dan berkembangnya ilmu pengetahuan dan teknologi, kita telah mengenal media pembelajaran yang berbasis audio dan visual atau biasa disebut dengan media audio visual, yaitu media yang mempunyai unsur suara dan unsur gambar. ${ }^{7}$ Media ini mempunyai kemampuan yang lebih, karena media ini mengandalkan dua indera sekaligus, yaitu indera pendengaran dan indera penglihatan. Maka, diharapkan proses pembelajaran dengan menggunakan media audio visual dapat merangsang minat siswa dalam mengikuti kegiatan pembelajaran hingga selesai dan memperjelas materi yang disampaikan serta mengarahkan perubahan pada diri siswa secara terencana, baik dalam aspek pengetahuan, sikap, maupun keterampilan.

Ketika melakukan studi pendahuluan di lapangan, yakni pada mata pelajaran Al Quran Hadis di kelas XI IPA Madrasah Aliyah (MA) Al Maunah yang mana mata pelajaran tersebut dijadwalkan setiap hari Selasa, pada jam ke-1 sampai ke-2, peneliti mengamati pembelajaran yang berlangsung dari awal pengajar masuk hingga beliau keluar kelas. Fakta yang tertangkap oleh peneliti di awal penelitian adalah minimnya peserta didik yang hadir untuk mengikuti pembelajaran saat itu. Namun pembelajaran tetap berjalan disertai kedatangan satu persatu peserta didik yang terlambat masuk ke kelas dengan santainya, bahkan ada beberapa

${ }^{7}$ Syaiful Bahri Djamarah, Psikologi Belajar (Jakarta: PT. Rineka Cipta, 2002), 21. 
dari mereka masuk dengan sisa beberapa menit saja sebelum pelajaran berakhir. Mereka membawa alasan yang beraneka ragam.

Menyoroti proses pembelajaran di dalam kelas, pada pendahuluan guru memulai dengan salam, mengabsen, mengingat materi pembelajaran sebelumnya, kemudian berlanjut ke materi inti, yakni membaca ayat Al Quran/Hadis lalu berlanjut ke penjelasan, terakhir penutup. Dari sekian rentetan kegiatan pembelajaran pada dua jam penuh pelajaran itu, terlihat bahwa pembelajaran masih dikuasai oleh guru, artinya sebagian besar pembelajaran diperankan oleh guru itu sendiri, peran siswa sangat pasif.

Pada paruh pertama dalam pembelajaran, beberapa peserta didik terlihat menurunkan intensitas perhatiannya. Di tengah berlangsungnya ceramah guru, terlihat beberapa siswa yang asyik mengobrol dengan teman sebangkunya, ada juga yang sibuk mengipasi dirinya, tentu dengan alasan kepanasan meskipun waktu pembelajaran adalah pagi hari, ditambah lagi ruangan yang menjadi kelas mereka tergolong baru yang belum selesai dalam proses pembangunannya. Berangkat dari sini, artinya mereka sudah merasa kurang nyaman dengan suasana pembelajaran yang berlangsung.

Kurangnya pengaturan strategi pembelajaran juga menjadi salah satu sebab terjadi kurangnya minat dan perhatian peserta didik terhadap pembelajaran. Salah satunya adalah media pembelajaran yang dapat digunakan untuk memberikan kesan yang menarik dalam pembelajaran. Karena kesan pertama dalam pembelajaran adalah sesuatu yang penting demi kelancaran tahap selanjutnya.

Beberapa peserta didik lebih memilih mengalihkan perhatiannya dengan menyibukkan diri dengan merangkum materi di buku catatan dari pada fokus pada penjelasan guru. Setelah itu saat ditanya di luar pembelajaran, beberapa peserta didik menyatakan kebingungan mereka saat merangkum materi pelajaran Al Quran Hadis sehingga mereka menulis lebih banyak. Kebingungan itu mereka alami karena mereka kurang paham terhadap poin penting materi yang harus mereka rangkum. Hal ini disebabkan oleh kurangnya perhatian dan minat dalam menyimak 
penjelasan guru terkait materi, padahal penjelasan dari guru adalah poin penting materi yang seharusnya menjadi catatan bagi peserta didik.

Pada paruh kedua peneliti melihat kejenuhan peserta didik meningkat dengan adanya peserta didik yang mulai mengantuk bahkan tertidur. Jika para peserta didik sudah mencapai puncak kejenuhannya dan dibiarkan terus menerus berada pada kondisi yang kurang kondusif, maka bagaimana tujuan pembelajaran akan tercapai dengan baik. Semula persiapan yang sudah terencana akan menjadi kurang maksimal jika para peserta didik kurang berminat dalam mengikuti pembelajaran.

Media audio visual diharapkan akan mampu memberikan pengaruh positif dalam rangka meningkatkan minat belajar pada mata pelajaran $\mathrm{Al}$ Quran Hadis siswa kelas XI IPA Madrasah Aliyah (MA) Al Maunah Kepuh, yang mana penelitian ini akan fokus pada materi bab IX yakni Hidup Lebih Sehat dengan Makanan yang Halal dan Baik yang mana bersandar pada dalil QS. Al-Baqarah [2]:168-169; QS. Al-Baqarah [2]: 172-173; dan hadis. Adapun perumusan masalahnya yaitu:

1. Bagaimana penggunaan media audio visual pada mata pelajaran $\mathrm{Al}$ Quran Hadis kelas XI IPA Madrasah Aliyah (MA) Al Maunah?

2. Bagaimana minat belajar siswa dengan menggunakan media audio visual pada mata pelajaran Al Quran Hadis kelas XI IPA Madrasah Aliyah (MA) Al Maunah?

3. Bagaimana pengaruh penggunaan media audio visual terhadap minat belajar siswa pada mata pelajaran Al Quran Hadis kelas XI IPA Madrasah Aliyah (MA) Al Maunah?

Adapun tujuan yang hendak dicapai oleh peneliti adalah:

1. Untuk mengetahui penggunaan media audio visual pada mata pelajaran Al Quran Hadis kelas XI IPA Madrasah Aliyah (MA) Al Maunah.

2. Untuk mengetahui minat belajar siswa dengan menggunakan media audio visual pada mata pelajaran Al Quran Hadis kelas XI IPA Madrasah Aliyah (MA) Al Maunah. 
3. Untuk mengetahui pengaruh penggunaan media audio visual terhadap minat belajar siswa pada mata pelajaran Al Quran Hadis kelas XI IPA Madrasah Aliyah (MA) Al Maunah.

Dalam penelitian ini, penulis mengambil langkah-langkah sebagai berikut:

1. Observasi

Observasi diartikan sebagai pengamatan secara langsung. Observasi dilakukan untuk mengamati secara langsung kegiatan di sekolah, guru dan siswa kelas XI IPA Madrasah Aliyah (MA) Al Maunah.

2. Angket

Angket adalah sejumlah pertanyaan tertulis yang digunakan untuk memperoleh informasi dari responden. ${ }^{8}$ Jadi, angket akan disebar ke seluruh responden untuk mengetahui jawaban tertulis atas pertanyaan yang diajukan di dalamnya terkait dengan penggunaan media audio visual dan minat belajar siswa.

3. Dokumentasi

Dokumentasi ini merupakan suatu cara atau teknik memperoleh data mengenai hal-hal atau variable yang berupa catatan, transkip, buku, surat kabar, majalah, prasasti, notulen rapat, agenda dan sebagainya. ${ }^{9}$ Dalam penelitian ini, dokumentasi digunakan untuk menggali data mengenai gambaran umum sekolah, keadaan guru, karyawan, maupun siswa, data penilaian autentik dan hasil belajar siswa, ini dilakukan untuk melengkapi data penelitian tentang adminstrasi kegiatan sekolah, serta memperoleh data tentang berdirinya sekolah, struktur organisasi, sarana prasarana, jumlah guru dan siswa di Madrasah Aliyah (MA) Al Maunah.

\section{B. Penggunaan Media Audio Visual dalam Meningkatkan Minat Belajar}

8 Suharsimi Arikunto, Prosedur Penelitian Suatu Pendekatan Praktik cet. ke-13 (Jakarta: PT. Rineka Cipta, 2006), 107.

${ }^{9}$ Suharsimi Arikunto, Prosedur Penelitian Suatu Pendekatan Praktik, 231. 


\section{pada Mata Pelajaran Al Quran Hadis}

Penelitian ini dilaksanakan di Madrasah Aliyah (MA) Al Maunah yang bertempat di jalan Ki Ageng Tepak Pasar Minggu-Kramat, desa Kepuh, kecamatan Palimanan, kabupaten Cirebon. Adapun waktu penelitian dilaksanakan pada semester genap tahun ajaran 2016/2017, yaitu dimulai dari bulan April sampai dengan bulan Mei 2017.

Madrasah Aliyah (MA) Al Maunah desa Kepuh, kecamatan Palimanan, kabupaten Cirebon ini telah beroperasi sejak tahun 2003. Status kepemilikan tanah yakni tanah wakaf, dan bangunannya adalah milik yayasan. Berdiri diatas tanah seluas $2.600 \mathrm{~m}^{2}$ dan memiliki bangunan seluas $256 \mathrm{~m}^{2}$.

Madrasah Aliyah (MA) Al Maunah saat ini dipimpin oleh Drs. H. Sodikin. Secara deskriptif Madrasah Aliyah (MA) Al Maunah ini di bawah naungan Yayasan Pendidikan Islam Al Maunah (YAPISMAH) yang letaknya satu wilayah dengan Taman Kanak-Kanak Islam (TKI), Madrasah Tsanawiyah (MTs), dan Pondok Pesantren Al Maunah itu sendiri.

Waktu penelitian jika dilihat berdasarkan Surat Keputusan Nomor: 2136/In.08/PP.009/03/2017 dilaksanakan pada bulan 01 Maret s.d 30 Mei 2017.

Sumber data yang digunakan dalam penelitian ini adalah: (1) data primer, yaitu data yang diperoleh dari lapangan penelitian di Madrasah Aliyah (MA) Al Maunah, seperti Wakil Kepala Bidang Kurikulum, Wakil Kepala Bidang Kesiswaan, Guru mata pelajaran Al Quran Hadis, staf Tata Usaha (TU) dan siswa, (2) data sekunder, yaitu data yang diperoleh untuk melengkapi data primer yang sudah ada. Data yang digunakan untuk mencari landasan teori tentang permasalahan yang diteliti dengan menggunakan buku-buku yang ada hubungannya dengan media audio visual dan minat belajar yang dijadikan sebagai rujukan.

Dalam penelitian ini, penulis menggunakan penelitian kuantitatif. Penelitian kuantitatif adalah jenis data yang dapat diukur atau dihitung 
secara langsung, yang berupa informasi atau penjelasan yang dinyatakan dengan bilangan atau berbentuk angka. ${ }^{10}$ Dari angka- angka itu akan dianalisis lebih lanjut lewat proses analisis data. Penelitian ini terdiri dari dua variabel, yang pertama adalah variabel terikat (dependent) yakni media audio visual dan kedua adalah variabel bebas (independent) yakni minat belajar.

Populasi adalah keseluruhan subjek penelitian. ${ }^{11}$ Dalam penelitian ini, populasinya yaitu seluruh siswa Madrasah Aliyah (MA) Al-Maunah yang berjumlah 107 siswa.

Sampel adalah sebagian atau wakil populasi yang diteliti. ${ }^{12}$ Sampel memberikan suatu gambaran tentang populasi pengambilan sampel dan suatu populasi disebut dengan penarikan sampel atau sampling.

Berdasarkan data populasi di atas, penulis memilih kelas XI IPA yang berjumlah 21 siswa untuk ikut andil sebagai sampel yang dituju. Adapun teknik penelitian ini adalah cluster sampling. Menurut Sugiyono cluster sampling adalah teknik yang digunakan untuk menentukan sampel bila objek yang akan diteliti terlalu luas, teknik ini digunakan bilamana populasi tidak terdiri dari individu-individu, melainkan terdiri dari kelompok- kelompok individu atau cluster. $^{13}$

Dalam penelitian ini terdapat dua variabel sebagai acuan dalam pengamatan, guna memperoleh data dan kesimpulan terkait penggunaan media audio visual dengan minat belajar siswa:

1. Variabel independen (variabel bebas) yaitu minat belajar sebagai variabel Y.

2. Variabel dependen (variabel terikat) yaitu media audio visual sebagai variabel X.

Dalam proses pencarian data, penulis menggunakan beberapa metode pengumpulan data sebagai berikut: 2014), 15.

10 Sugiyono, Metode Penelitian Kuantitatif, Kualitatif, dan R\&D (Bandung: Alfabeta,

${ }^{11}$ Suharsimi Arikunto, Prosedur Penelitian Suatu Pendekatan Praktik, 130.

${ }^{12}$ Suharsimi Arikunto, Prosedur Penelitian Suatu Pendekatan Praktik, 131.

${ }^{13}$ Sugiyono, Metode Penelitian Kuantitatif, Kualitatif, dan R\&D, 121. 
1. Observasi

Observasi diartikan sebagai pengamatan secara langsung. Observasi dilakukan untuk mengamati secara langsung kegiatan di sekolah, guru dan siswa kelas XI IPA Madrasah Aliyah (MA) Al Maunah.

2. Angket

Angket adalah sejumlah pertanyaan tertulis yang digunakan untuk memperoleh informasi dari responden. ${ }^{14}$ Jadi, angket akan disebar ke seluruh responden untuk mengetahui jawaban tertulis atas pertanyaan yang diajukan di dalamnya.

Soal angket terdiri dari 20 soal dengan 5 opsi jawaban sebagai berikut:

Tabel 3.1

Bobot Skor

\begin{tabular}{lcc}
\hline \multirow{2}{*}{ Jawaban Alternatif } & \multicolumn{2}{c}{ Skor Pertanyaan } \\
\cline { 2 - 3 } & Positif & Negatif \\
\hline Selalu & 5 & 1 \\
Sering & 4 & 2 \\
Kadang- Kadang & 3 & 3 \\
Pernah & 2 & 4 \\
Tidak Pernah & 1 & 5 \\
\hline
\end{tabular}

3. Dokumentasi

Dokumentasi ini merupakan suatu cara atau teknik memperoleh data mengenai hal-hal atau variable yang berupa catatan, transkip, buku, surat kabar, majalah, prasasti, notulen rapat, agenda dan sebagainya. ${ }^{15}$ Dalam penelitian ini, dokumentasi digunakan untuk menggali data mengenai gambaran umum sekolah, keadaan guru,

${ }^{14}$ Suharsimi Arikunto, Prosedur Penelitian Suatu Pendekatan Praktik, 107.

${ }^{15}$ Suharsimi Arikunto, Prosedur Penelitian Suatu Pendekatan Praktik, 231. 
karyawan, maupun siswa, data penilaian autentik dan hasil belajar siswa, ini dilakukan untuk melengkapi data penelitian tentang adminstrasi kegiatan sekolah, serta memperoleh data tentang sejarah berdirinya sekolah, struktur organisasi, sarana prasarana, jumlah guru dan siswa di Madrasah Aliyah (MA) Al Maunah.

\section{Teknik Analisi Data}

Teknik analisis data yang digunakan dalam penelitian ini adalah sebagai berikut.

\section{Teknik Analisa Prosentase}

Semua data-data yang telah berhasil dikumpulkan akan dibahas oleh penulis dengan menggunakan metode analisis deskriptif, yaitu menjelaskan data-data yang diperolehnya dengan menggunakan perhitungan prosentase atau bisa disebut frekuensi relative.

Sebelum penulis menjabarkan hasil data secara korelasi product moment, maka sebelumnya penulis akan menghitung nilai frekuensi prosentasi relatif atas penelitian sebagai bentuk table prosentase. Teknik ini untuk menjawab pada rumusan masalah nomor 1, 2, dan 3.

Untuk memperoleh frekuensi relative, digunakan rumus:

$$
P=\frac{F}{N} X 100 \%
$$

Keterangan:

$\mathrm{P}=$ Prosentase

$\mathrm{F}=$ Jumlah orang yang menjawab alternative

$\mathrm{N}=$ Jumlah respon ${ }^{16}$

Untuk menilai skala presentase digunakan rumus sebagai berikut:

$$
\begin{aligned}
& 100 \%: \text { Seluruh responden } \\
& 90 \%-99 \%: \text { Hampir seluruhnya }
\end{aligned}
$$

16 Anas Sudijono, Pengantar Statistik Pendidikan (Jakarta: PT. Raja Grafindo, 2006), 42-43. 


$$
\begin{aligned}
& 60 \%-89 \% \text { : Sebagian besar } \\
& 51 \%-59 \% \text { : Lebih dari setengahnya } \\
& 50 \% \text { : Setengahnya } \\
& \text { 40\% - 49\% : Hampir setengahnya } \\
& \text { 20\% - 39\% : Sebagian kecil } \\
& 1 \%-19 \% \quad \text { : Sedikit sekali } \\
& \text { 0\% : Tidak ada }{ }^{17}
\end{aligned}
$$

Adapun untuk memberikan nilai pada angket, penulis memberikan ketentuan sebagai berikut:

Untuk item soal positif:
a. Untuk skor jawaban A diberi nilai 5
b. Untuk skor jawaban B diberi nilai 4
c. Untuk skor jawaban $\mathrm{C}$ diberi nilai 3
d. Untuk skor jawaban D diberi nilai 2
e. Untuk skor jawaban $\mathrm{E}$ diberi nilai 1

Untuk item soal negatif:
a. Untuk skor jawaban A diberi nilai 1
b. Untuk skor jawaban B diberi nilai 2
c. Untuk skor jawaban $\mathrm{C}$ diberi nilai 3
d. Untuk skor jawaban $\mathrm{D}$ diberi nilai 4
e. Untuk skor jawaban $\mathrm{E}$ diberi nilai 5

Setelah mendapatkan hasil berupa prosentase, hasilnya dapat ditafsirkan sebagai berikut:

Tabel 3.2

Tafsiran Prosentase 18

Prosentase Penafsiran

${ }^{17}$ Suharsimi Arikunto, Prosedur Penelitian Suatu Pendekatan Praktik, 167.

${ }^{18}$ Suharsimi Arikunto, Prosedur Penelitian Suatu Pendekatan Praktik, 246. 


\begin{tabular}{ll}
\hline $75 \%-100 \%$ & Baik \\
$55 \%-74 \%$ & Cukup \\
$40 \%-54 \%$ & Kurang \\
$0 \%-39 \%$ & Tidak baik \\
\hline
\end{tabular}

\section{Teknik Analisa Product Moment}

Untuk menjawab rumusan masalah nomor 3 yaitu ada tidaknya pengaruh media audio visual terhadap minat belajar siswa pada pembelajaran Al Quran Hadis kelas XI IPA Madrasah Aliyah (MA) Al Maunah, maka penulis menggunakan rumusan korelasi product moment sebagai berikut:

$$
r_{x y}=\frac{\mathrm{N} \sum \mathrm{XY}-\left(\sum \mathrm{X}\right)\left(\sum \mathrm{Y}\right)}{\left\{\mathrm{N} \sum \mathrm{X}^{2}-\left(\sum \mathrm{X}\right)^{2}\right\}\left\{\left(\mathrm{N} \sum \mathrm{Y}^{2}-\left(\sum \mathrm{Y}\right)^{2}\right\}\right.}
$$

Keterangan:

$$
\begin{array}{ll}
\text { rxy } & : \text { Angka indeks korelasi " } r " \\
\mathrm{~N} & : \text { Jumlah responden/siswa } \\
\sum \mathrm{xy} & : \text { Jumlah hasil penilaian antara skor } \mathrm{x} \text { dan skor } \mathrm{y} \\
\sum \mathrm{x} & \text { : Jumlah seluruh skor } \mathrm{X} \\
\sum \mathrm{y} & \text { : Jumlah seluruh skor } \mathrm{Y}
\end{array}
$$

Setelah itu, hasilnya diinterpretasikan dengan menggunakan cara memberikan interpretsi terhadap angka indeks korelasi " $r$ " product moment dengan cara kasar/sederhana dengan menggunakan pedoman standar penilaian ${ }^{19}$ sebagai berikut:

a. Memberikan interprestasi secara kasar / sederhana

Tabel 3.3

Interpretasi Besarnya "r"

\section{Besarnya "r"}

\section{product}

\section{Interprestasi}

${ }^{19}$ Suharsimi Arikunto, Prosedur Penelitian .........., 319.

Al-Tarbawi Al-Haditsah: Jurnal Pendidikan Islam

Vol. 2, No. 2, Desember 2017 


\begin{tabular}{|c|c|}
\hline moment (rxy) & \\
\hline \multirow{3}{*}{$0,90-1,00$} & Antara variabel x dan variabel \\
\hline & y terdapat korelasi yang sangat \\
\hline & kuat/ tinggi \\
\hline \multirow{3}{*}{$0,70-0,90$} & Antara variabel $\mathrm{x}$ dan variabel \\
\hline & y terdapat korelasi yang kuat / \\
\hline & tinggi \\
\hline \multirow{3}{*}{$0,40-0,70$} & Antara variabel $\mathrm{x}$ dan variabel \\
\hline & y terdapat korelasi yang \\
\hline & sedang atau cukup \\
\hline \multirow{3}{*}{$0,20-0,40$} & Antara variabel x dan variabel \\
\hline & y terdapat korelasi yang lemah \\
\hline & atau rendah \\
\hline \multirow{4}{*}{$0,00-0,20$} & Antara variabel $\mathrm{x}$ dan variabel \\
\hline & y memang terdapat korelasi, \\
\hline & akan tetapi itu sangat lemah / \\
\hline & sangat rendah \\
\hline
\end{tabular}

b. Memberikan interprestasi dengan cara berkonsultasi pada tabel nilai " $r$ " product moment. Agar lebih mudah terprestasi terhadap angka dekskorelasi " $r$ " product moment dapat ditempuh dengan jalan berkonsultasi pada tabel "r" product moment, prodesurnya adalah sebagai berikut:

1) Merumuskan hipotesa alternative (Ha) dan hipotesa nihil (Ho)

2) Koefesien Determinasi

Untuk mengetahui berapa persen penggunaan media audio visual sebagai variabel $\mathrm{X}$ dan minat belajar siswa kelas XI Madrasah Aliyah (MA) Al Maunah sebagai variabel Y, penulis menggunakan rumus koefesien determinasi $(\mathrm{KD})$ sebagai berikut:

$$
\mathrm{KD}=\left(\mathrm{r}_{\mathrm{xy}}\right)^{2} \times 100 \%
$$

Keterangan: 


$\begin{array}{ll}\mathrm{KD} & : \text { Koefesien Determinasi } \\ \mathrm{r}_{\mathrm{xy}} & : \text { hasil nilai observasi yang dikuadratkan } \\ 100 \% & : \text { persentase }\end{array}$

Dalam hal ini, nilai $r_{x y}$ diartikan sebagai koefesien validasi, sehingga kriterianya menjadi:

$$
\begin{aligned}
& 0,80-1,00: \text { korelasi tinggi } \\
& 0,60-0,80: \text { korelasi cukup } \\
& 0,40-0,60: \text { korelasi sedang } \\
& 0,20-0,40: \text { korelasi rendah } \\
& 0,00-0,20: \text { korelasi sangat rendah }
\end{aligned}
$$

\section{Uji Hipotesis}

Uji hipotesis dilakukan dengan menggunakan rumus $t_{\text {tes atau }} t_{\text {hitung }}$ sebagai berikut:

$$
t_{\text {hitung }}=\frac{r \sqrt{n-2}}{\sqrt{1-r^{2}}}
$$

Dimana:

$$
\begin{aligned}
& r=\text { Koefisien korelasi } \\
& n=\text { Banyaknya responden }
\end{aligned}
$$

\section{Hipotesis Statistik}

Hipotesis adalah suatu jawaban yang bersifat sementara terhadap permasalahan penelitian, sampai terbukti melalui data yang terkumpul. ${ }^{20}$ Dalam penelitain ini hipotesis yang diajukan adalah sebagai berikut:

Pengujian hipotesis penelitian dilakukan dengan pasangan hipotesis statistik dalam bentuk $\mathrm{H}_{\mathrm{o}}$ dan $\mathrm{H}_{\mathrm{a}}$. Adapun hipotesis penelitian diatas maka hipotesis statistiknya adalah $\mathrm{H}_{\mathrm{o}}$ ditolak dan $\mathrm{H}_{\mathrm{a}}$ diterima. Hipotesis yang akan diuji dalam penelitian ini adalah:

Ha: Adanya pengaruh penggunaan media audio visual terhadap minat belajar siswa pada mata pelajaran Al Quran Hadits kelas XI IPA

\footnotetext{
${ }^{20}$ Suharsimi Arikunto, Prosedur Penelitian.........., 71.
} 
Madrasah Aliyah (MA) Al Maunah Desa Kepuh Kecamatan

Palimanan Kabupaten Cirebon

Ho: Tidak ada pengaruh penggunaan media audio visual terhadap minat

belajar siswa pada mata pelajaran Al Quran Hadits kelas XI IPA

Madrasah Aliyah (MA) Al Maunah Desa Kepuh Kecamatan

Palimanan Kabupaten Cirebon

Berdasarkan rumusan di atas nilai koefisien (rxy) perlu diuji. Untuk menguji penulis menggunakan rumus sebagai berikut:

thitung $=\frac{r \sqrt{n-2}}{\sqrt{1-r^{2}}}$

keterangan:

$\mathrm{r}=$ Koefisien korelasi product moment

$\mathrm{n}=$ Number of cases (banyaknya sampel)

Dengan ketentuan:

Jika $t_{\text {hitung }} \geq t_{\text {tabel }}$ maka hipotesis nol ditolak dan hipotesis alternative diterima.

Jika $\mathrm{t}_{\text {hitung }} \leq \mathrm{t}_{\text {tabel }}$ maka hipotesis nol diterima dan hipotesis alternative ditolak. ${ }^{21}$

\section{Kesimpulan}

Berdasarkan hasil penelitian tentang Penggunaan Media Audio Visual dalam Meningkatkan Minat Belajar pada Mata Pelajaran Al Quran Hadis Siswa Kelas XI IPA Madrasah Aliyah (MA) Al Maunah Desa Kepuh Kecamatan Palimanan Kabupaten Cirebon yang telah dilakukan dapat disimpulkan bahwa:

Pertama, penggunaan media audio visual pada mata pelajaran Al Quran Hadis kelas XI IPA Madrasah Aliyah (MA) Al Maunah sudah cukup. Hal ini terbukti dari hasil rata-rata pencapian penggunaan media audio visual yang sebagian besar berada pada kategori baik dengan rata-

${ }^{21}$ Riduwan dan Sunarto, Pengantar Statistika Untuk Penelitian Pendidikan, Social, Ekonomi, Komunikasi Dan Bisnis (Bandung: Alfabeta, 2008), 299. 
rata prosentase pencapaian sebesar $92 \%$ karena berada pada interval 75 $\%-100 \%$.

Kedua, minat belajar siswa dengan menggunakan media audio visual pada mata pelajaran Al Quran Hadis kelas XI IPA Madrasah Aliyah (MA) Al Maunah yang dilihat hasil perhitungan angket diperoleh rata-rata pencapaian minat belajar siswa kelas XI IPA sebesar 87,4\% termasuk kategori baik, ini membuktikan bahwa minat belajar siswa pada mata pelajaran Al-Qur’an Hadis di Madrasah Aliyah (MA) Al Maunah Desa Kepuh Kecamatan Palimanan Kabupaten Cirebon dipengaruhi oleh penggunaan media audio visual.

Ketiga, pengaruh penggunaan media audio visual terhadap minat belajar pada mata pelajaran Al Quran Hadis siswa kelas XI IPA Madrasah Aliyah (MA) Al Maunah terdapat korelasi cukup atau sedang. Hal ini dapat dibuktikan dari perhitungan koefisien korelasi dengan nilai 0,60 yang berada pada rentang $0,40-0,70$. 


\section{DAFTAR PUSTAKA}

Arikunto, Suharsimi, 2006. Prosedur Penelitian Suatu Pendekatan Praktik cet. ke-13. Jakarta: PT. Rineka Cipta.

Asnawir dan Usman, Basyiruddin, 2002. Media Pembelajaran. Jakarta: Ciputat Pers.

Bahri Djamarah, Syaiful, 2002. Psikologi Belajar. Jakarta: PT. Rineka Cipta.

Djaali, Haji, 2014. Psikologi Pendidikan Jakarta: Bumi Aksara.

Riduwan dan Sunarto, 2008. Pengantar Statistika Untuk Penelitian Pendidikan, Social, Ekonomi, Komunikasi Dan Bisnis. Bandung: Alfabeta.

Sudijono, Anas, 2006. Pengantar Statistik Pendidikan. Jakarta: PT. Raja Grafindo.

Sudjana, Nana, dan Ahmad Rivai, 2005. Media Pengajaran. Bandung: Sinar Baru Algensindo.

Sugiyono, 2014. Metode Penelitian Kuantitatif, Kualitatif, dan R\&D. Bandung: Alfabeta.

Suprijanto. 2005. Pendidikan Orang Dewasa. Jakarta: PT. Bumi Aksara.

UU RI No. 20 Tahun 2003. 2011. Sistem Pendidikan Nasional. Jakarta: Sinar Grafika. 